\title{
Novel targeted therapies and immunotherapy for advanced thyroid cancers
}

\author{
George E. Naoum ${ }^{1,2}$, Michael Morkos ${ }^{3}$, Brian Kim $^{4}$ and Waleed Arafat ${ }^{2,5,6^{*}}$
}

\begin{abstract}
Thyroid cancer is a frequently encountered endocrine malignancy. Despite the favorable prognosis of this disease, 15-20\% of differentiated thyroid cancer (DTC) cases and most anaplastic types, remain resistant to standard treatment options, including radioactive iodine (RAI). In addition, around 30\% of medullary thyroid cancer (MTC) cases show resistance after surgery. The evolving understanding of disease-specific molecular therapeutic targets has led to the approval of two targeted therapies (Sorafenib and Lenvatinib) for RAI refractory DTC and another two drugs (Vandetanib and Cabozantinib) for MTC. These advanced therapies exert their effects by blocking the MAPK pathway, which has been widely correlated to different types of thyroid cancers. While these drugs remain reserved for thyroid cancer patients who failed all treatment options, their ability to improve patients' overall survival remain hindered by their low efficacy and other molecular factors. Among these factors is the tumor's ability to activate parallel proliferative signaling pathways other than the cascades blocked by these drugs, along with overexpression of some tyrosine kinase receptors (TKR). These facts urge the search for novel different treatment strategies for advanced thyroid cases beyond these drugs. Furthermore, the growing knowledge of the dynamic immune system interaction with tumor microenvironment has revolutionized the cancer immune therapy field. In this review, we aim to discuss the molecular escape mechanisms of thyroid tumors from these drugs. We also highlight novel therapeutic options targeting other pathways than MAPK, including PI3K pathway, ALK translocations and HER2/3 receptors and their clinical impact. We also aim to discuss the usage of targeted therapy in restoring thyroid tumor sensitivity to RAl, and finally turn to extensively discuss the role of immunotherapy as a potential alternative treatment option for advanced thyroid diseases.
\end{abstract}

\section{Background}

For the past several decades thyroid cancer has been the most common endocrine tumor, with a $5 \%$ increase in incidence each year in the USA $[1,2]$. The vast majority of thyroid cancers arise from thyroid follicular cells (93\%) and are well-differentiated (DTC). Most of these are categorized on histologic grounds as being papillary thyroid cancers (PTC), or less commonly as follicular thyroid cancers (FTC), the latter being associated with a worse prognosis. Poorly differentiated forms with even more aggressive clinical behavior are relatively uncommon and the highly fatal anaplastic thyroid cancers (ATC) are fortunately rare [3, 4]. Parafollicular cell-

\footnotetext{
* Correspondence: w.o.arafaat@gmail.com

${ }^{2}$ Alexandria Comprehensive Cancer center, Alexandria, Egypt

${ }^{5}$ University Of Alexandria, Clinical oncology department, Alexandria, Egypt

Full list of author information is available at the end of the article
}

derived medullary thyroid cancers (MTC) are also rare, comprising $~ 3 \%$ of thyroid carcinomas [5].

The standard therapeutic approach to all thyroid cancers includes surgery, with radioactive iodine (RAI) being offered to some patients with follicular cell-derived thyroid cancers [6-8].

A small fraction $(<10 \%)$ of DTC as well as many MTCs and almost all ATCs are not cured by standard therapy, instead spreading to distant metastatic sites. If grouped together as "advanced thyroid cancers," patients with these aggressive forms have a less than $50 \% 5$ year survival rate in contrast to the $\sim 98 \% 5$-year survival for iodine-sensitive DTC patients [9].

Recently, a number of scientific advances have illuminated some of the molecular pathways responsible for thyroid cancer. This growing knowledge raises the hope 
that it will soon be possible to develop specific therapeutics tailored to these molecular changes [10]. While multiple kinase inhibitor drugs (MKIs) targeting MAPK pathway have had some clinical benefit, improvements in overall survival is still debatable [11]. Both the presence of tumoral intrinsic resistance mechanisms to these MKIs, as well as the systemic toxicity of the drugs have limited their clinical benefits [12]. Therefore, novel approaches must be explored for advanced thyroid cancers.

This review article considers the major therapeutic strategies currently being investigated in the field of advanced thyroid cancer, focusing on approaches with not only preclinical but also clinical trial data. We aim to discuss novel and experimental MKIs for advanced thyroid cancers, radioactive iodine (RAI) resensitization and finally a section on immunotherapy.

It is to be noted that search strategy and selection criteria and references for this Review were identified through searches of PubMed, "clinicaltrials.gov", and oncology conferences' websites with the search terms "thyroid cancer", "targeted therapy", "MAPK", "radioactive iodine refractory thyroid cancer", and "immunotherapy for thyroid cancer" since inception. Only papers published in English were reviewed. The references were included based on their pertinence to the scope of this Review

\section{MKIs in advanced thyroid cancer}

The MAPK signaling pathway (Fig. 1) is one of the most extensively studied pathways in oncology [13]. Upon pathologic activation of different tyrosine kinase receptors (TKR), a cascade of downstream events in this pathway ultimately leads to cell proliferation, differentiation, and survival. Data from the cancer genome atlas (TCGA), has allowed better classification and molecular characterization of PTC, using integrated multiplatform data with a large sample size [14]. According to this data, PTC has been classified as an MAPK driven tumor with the two major signaling drivers being $B R A F^{\mathrm{V} 600 \mathrm{E}}$ and mutated RAS. In addition, mutations in PI3K pathways, as well as a few genetic somatic mutations and fusion alterations have been reported (with lower frequency) in PTC [14]. In Table 1, major drivers of thyroid cancer are identified.

At the time of this writing, the FDA has approved four different drugs targeting the Mitogen-Activated Protein Kinase (MAPK) signaling pathway in the treatment of
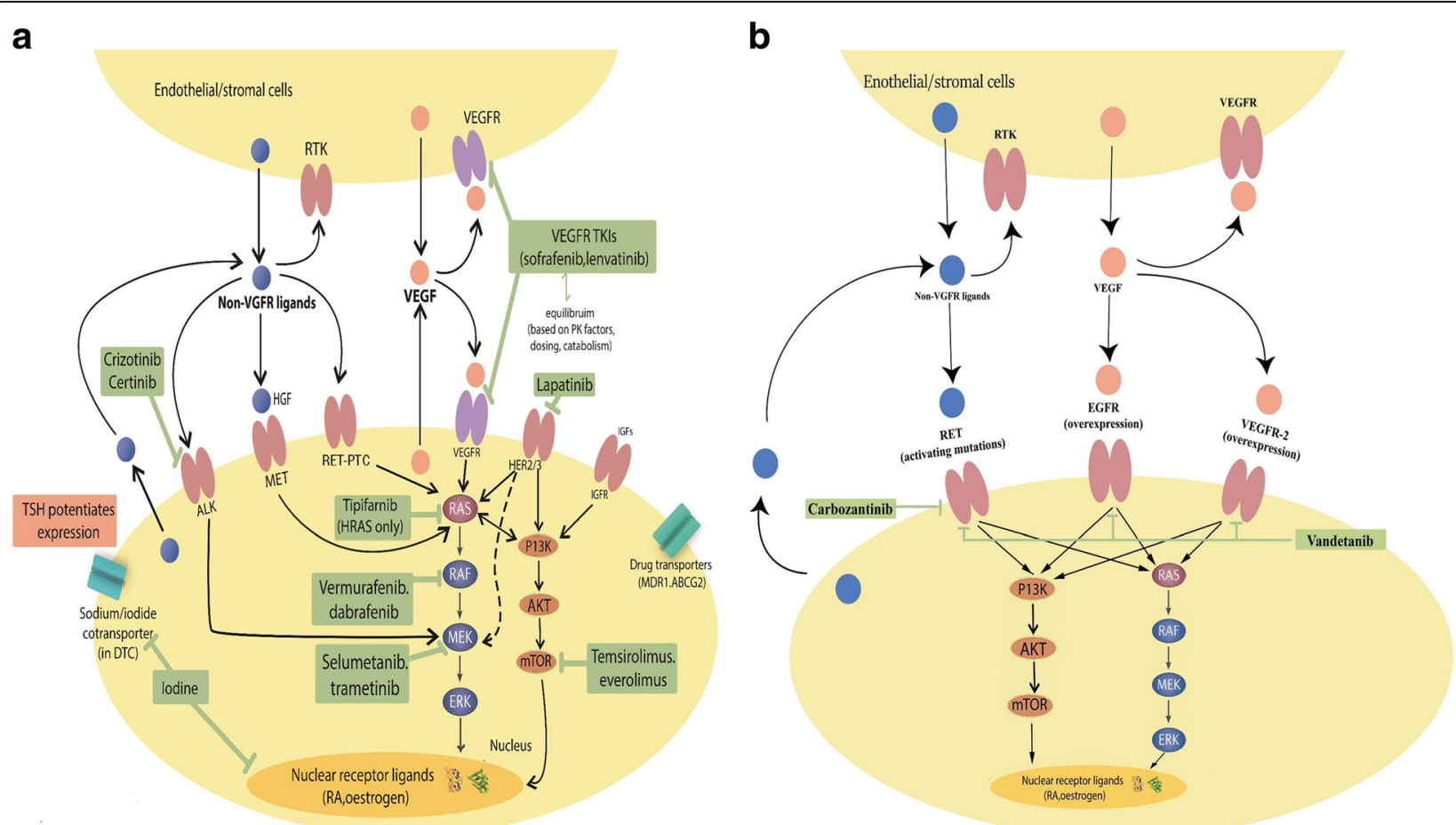

Fig. 1 Dominant signaling pathways involved in thyroid cancers, and clinically relevant inhibitors: a: MAPK and PI3k tyrosine kinase Receptors are shown in DTC cells, along with their respective ligands and downstream cascades. All clinically approved drugs are highlighted in green. The cross talk between MAPK and PI3k is shown through RAS and represent a tumoral escape mechanism from known multiple kinases inhibitors acting on B-RAF. ALK and Her2/3 receptors are shown with their downstream signaling pathways representing another tumoral escape mechanism from conventional drugs working on RAS and RAF. Note that stromal and endothelial cells, as well as cancer cells, participate in VEGFR and other signalling pathways that contribute cancer proliferation. $\mathbf{b}$ the regulating pathways of MTC cells are shown with the same cross talk between MAPK and RAS. MTC approved targeted therapy with their corresponding targets and receptors 
Table 1 Mutations in thyroid cancers

\begin{tabular}{|c|c|c|c|}
\hline Thyroid cancer type & Mutation & Description and significance & Reference \\
\hline \multirow[t]{7}{*}{ Differentiated thyroid cancers } & $B-R A F$ & $\begin{array}{l}\text { B-RAF point mutations (particularly glutamate } \\
\text { substitution for valine at residue } 600, \text { V600E) are } \\
\text { present in } 30-70 \% \text { of patients with PTC }\end{array}$ & {$[96-104]$} \\
\hline & RAS & $\begin{array}{l}\text { RAS oncogene mutations are manifested in } 15-20 \% \text { of } \\
\text { PTC and } 40-50 \% \text { of FTC }\end{array}$ & [105-111] \\
\hline & RET/PTC rearrangements & $\begin{array}{l}\text { RET/PTC1 and RET/PTC3 together comprise }>90 \% \text { of } \\
\text { RET/PTC mutations in thyroid cancer); RET/PTC2 } \\
\text { represents less than } 5 \% \text {. Combined, RET/PTC } \\
\text { rearrangements are found in } \sim 13 \% \text { of PTC }\end{array}$ & [112-119] \\
\hline & PAX8-PPARY translocations & $\begin{array}{l}\text { PAX8 drives the expression of many thyroid-specific } \\
\text { genes such as those encoding thyroglobulin, the } \\
\text { sodium iodide symporter and thyroid peroxidase. The } \\
\text { PAX8-PPARY translocations are found in } 35 \% \text { of FTC } \\
\text { and vascular invasion and tumor proliferation have } \\
\text { been linked to these translocations. }\end{array}$ & [120-125] \\
\hline & $\begin{array}{l}\text { Telomerase reverse transcriptase } \\
\text { gene (TERT) mutations }\end{array}$ & $\begin{array}{l}\text { Found to be overexpressed in DTC; } 11 \% \text { of FTC and } \\
16-40 \% \text { of PTC (frequently in association to B-RAF } \\
\text { mutations) were found to bear TERT mutations. } \\
\text { Coexistence of TERT with BRAF mutation was } \\
\text { concluded to have the worst prognosis for DTC } \\
\text { patients especially those with PTC subtype [126]. } \\
\text { However, studies examining TERT as a therapeutic } \\
\text { target are lacking. }\end{array}$ & [126-128] \\
\hline & PIK3CA & $\begin{array}{l}\text { PIk3CA gene encodes for catalytic subunits in PI3K } \\
\text { leading to activating the proliferative cascade of PI3K } \\
\text { AKT pathway. Increased copy numbers of this gene has } \\
\text { been found in } 24 \% \text { of FTC and } 42 \% \text { of ATC. }\end{array}$ & [25] \\
\hline & PTEN & $\begin{array}{l}\text { PTEN normally antagonizes and terminates the } \\
\text { signaling of the PISK A Akt pathway. It was found that } \\
\text { around } 12 \% \text { of ATC exhibit mutated or deleted PTEN } \\
\text { genes and hence over activation of the proliferative } \\
\text { PI3K pathway and more tumoral aggressiveness. }\end{array}$ & {$[25]$} \\
\hline Medullary thyroid cancers & RET mutations & $\begin{array}{l}>60 \% \text { of MTC have been linked to somatic RET } \\
\text { oncogene mutations. }\end{array}$ & [129] \\
\hline
\end{tabular}

advanced thyroid cancers $[15,16]$. These include Lenvatinib and Sorafenib for advanced, recurrent, and RAI-refractory (RAI-R) DTC; and Cabozantinib and Vandetanib for MTC. Also several MKIs targeting MAPK are being studied in advanced thyroid cancers but none of them have been FDA approved yet (Table 2). The approved targeted therapeutics exert their antitumoral activity mainly by competing with ATP at its binding site on the tyrosine kinase receptor (TKR) and partially by blocking several central mediators of MAPK pathway (Fig. 1). The mechanisms of these MKIs and their clinical impact have been extensively reviewed $[11,17-19]$. As the developmental history and clinical data for the FDA-approved MKIs have been recently reviewed elsewhere [11], that aspect is not considered here.

\section{MAPK and PI3K pathways cross talk and tumor escape mechanism}

To date, efforts based on pharmaceutically blocking MAPK increased progression-free survival in DTC and MTC [20]. A recent single study showed that
Lenvatinib achieved improvement in overall survival in older patients (> 65 years old) with advanced DTC in comparison to younger patients [21]. Also the same study showed that this old age group suffered from higher toxicity in comparison to younger patients, rendering debatable clinical decisions in today's practice. Other than systemic toxicity, the development of tumoral escape mechanisms to these drugs represents an additional limitation that should be considered more closely. Known tumoral escape cascades and mechanisms from MKI drugs include induction of either alternative signaling pathways or to tyrosine kinase receptor (TKR) upregulation on the tumoral cell surface [22-24]. As depicted in Fig. 1, the MAPK and PI3K-AKT cascades are overlapping, with upregulation of either pathway leading to the same end-result of tumor cell survival and proliferation. Some of the major PTC drivers, the RAS and RET/PTC oncogenes are essential components of MAPK pathway, with cross talk effects with the PI3KAKT cascade (Fig. 1). The role of PI3K-AKT cascade in initiating and promoting the progression of thyroid 
Table 2 Other MKIs for MAPK are being tested for different types of thyroid cancer but at the time of writing this article, none have reached phase III trials

\begin{tabular}{|c|c|c|c|c|c|c|c|c|}
\hline Drug & Drug targets & Phase & Dosage & Patients & $\begin{array}{l}\text { Partial } \\
\text { response } \\
\text { RR (\%) }\end{array}$ & $\begin{array}{l}\text { Progression- } \\
\text { free survival } \\
\text { PFS (months) }\end{array}$ & Adverse effects (\%) & $\begin{array}{l}\text { Drug } \\
\text { discontinuation }\end{array}$ \\
\hline \multicolumn{9}{|c|}{ Multikinase inhibitors } \\
\hline $\begin{array}{l}\text { Axitinib } \\
\text { [130] }\end{array}$ & $\begin{array}{l}\text { VEGFR, } \\
\text { PDGFR, c-kit }\end{array}$ & $\|$ & $\begin{array}{l}\text { starting dose of } \\
5 \mathrm{mg} \text { twice daily }\end{array}$ & 60 & 30 & 18.1 & $\begin{array}{l}\text { Fatigue }(50 \%) \text {, diarrhea }(48 \%), \\
\text { nausea }(33 \%) \text {, anorexia }(30 \%), \\
\text { hypertension ( } 28 \%) \text {, stomatitis } \\
(25 \%) \text {, weight loss }(25 \%) \text {, and } \\
\text { headache }(22 \%)\end{array}$ & $\begin{array}{l}32 \text { patients, } 8 \text { of } \\
\text { them due to } \\
\text { treatment side } \\
\text { effects }\end{array}$ \\
\hline $\begin{array}{l}\text { Motesanib } \\
{[131]}\end{array}$ & $\begin{array}{l}\text { VEGFR, } \\
\text { PDGFR, c-kit }\end{array}$ & $\|$ & $\begin{array}{l}125 \mathrm{mg} / \text { day orally } \\
\text { for up to } 48 \text { weeks }\end{array}$ & 93 & 14 & 9.3 & $\begin{array}{l}\text { Diarrhea (59\%), hypertension } \\
(56 \%), \text { fatigue }(46 \%) \text {, and weight } \\
\text { loss (40\%) }\end{array}$ & $\begin{array}{l}61 \text { patients, } 12 \text { of } \\
\text { them due to } \\
\text { treatment side } \\
\text { effects }\end{array}$ \\
\hline $\begin{array}{l}\text { Sunitinib } \\
\text { [132] }\end{array}$ & $\begin{array}{l}\text { PDGFR, FLT3, } \\
\text { c-kit, VEGFR, } \\
\text { RET }\end{array}$ & $\|$ & 37.5 mg/day orally & 35 & 31 & 12.8 & $\begin{array}{l}\text { Neutropenia (34\%), fatigue (11\%), } \\
\text { HFS (17\%), diarrhea (17\%), and } \\
\text { leukopenia (31\%) }\end{array}$ & $\begin{array}{l}4 \text { patients due to } \\
\text { treatment side } \\
\text { effects }\end{array}$ \\
\hline $\begin{array}{l}\text { Pazopanib } \\
\text { [133] }\end{array}$ & $\begin{array}{l}\text { VEGFR, PDGFR, } \\
\text { c-kit }\end{array}$ & $\|$ & $\begin{array}{l}800 \text { mg/day orally } \\
\text { in 4-week cycle }\end{array}$ & 37 & 49 & 11.7 & $\begin{array}{l}\text { Fatigue }(78 \%) \text {, skin and hair } \\
\text { hypopigmentation }(75 \%), \\
\text { diarrhea }(73 \%) \text {, and nausea } \\
(73 \%)\end{array}$ & $\begin{array}{l}27 \text { patients, } 2 \text { of } \\
\text { them due to } \\
\text { treatment side } \\
\text { effects }\end{array}$ \\
\hline $\begin{array}{l}\text { Dovitinib } \\
{[134]}\end{array}$ & $\begin{array}{l}\text { FGFR, and } \\
\text { (VEGFR) }\end{array}$ & $\|$ & $\begin{array}{l}500 \mathrm{mg} / \text { day orally } \\
\text { for five consecutive } \\
\text { days, followed by a } \\
\text { 2-day rest every } \\
\text { week. }\end{array}$ & 40 & 20.5 & 5.4 & $\begin{array}{l}\text { Diarrhea }(54 \%) \text {, anorexia } \\
(36 \%) \text {, vomiting }(26 \%) \text {, } \\
\text { fatigue }(23 \%) \text {, and } \\
\text { nausea }(21 \%)\end{array}$ & 12 patients \\
\hline $\begin{array}{l}\text { Imatinib } \\
\text { [135] }\end{array}$ & $\begin{array}{l}\text { BCR-ABL, } \\
\text { PDGFR- } a \text {, } \\
\text { PDGFR- } \beta \text {, } \\
\text { c-fms, c-Kit, } \\
\text { and RET }\end{array}$ & $\|$ & 600 mg/day orally & 15 & 0 & NR & $\begin{array}{l}\text { Hypothyroidism }(60 \%), \text { rash, } \\
\text { malaise, and laryngeal } \\
\text { mucosal swelling (13\%) }\end{array}$ & $\begin{array}{l}10 \text { patients, } 3 \text { of } \\
\text { them due to } \\
\text { treatment side } \\
\text { effects }\end{array}$ \\
\hline $\begin{array}{l}\text { Selumetinib } \\
\text { (AZD6244) } \\
{[43]}\end{array}$ & $\begin{array}{l}\text { MEK-1/2 (one of } \\
\text { MAPK), RAS, } \\
\text { V600E BRAF }\end{array}$ & $\|$ & $\begin{array}{l}100 \mathrm{mg} \text { twice } \\
\text { daily for 28-days } \\
\text { cycles }\end{array}$ & 39 & 3 & 8 & $\begin{array}{l}\text { Rash }(77 \%) \text {, fatigue }(49 \%), \\
\text { diarrhea }(49 \%) \text {, and peripheral } \\
\text { edema }(36 \%)\end{array}$ & $\begin{array}{l}\text { Only } 6 \text { patients } \\
\text { due to treatment } \\
\text { side effects }\end{array}$ \\
\hline \multicolumn{9}{|c|}{ Selective BRAF inhibitors } \\
\hline $\begin{array}{l}\text { Dabrafenib } \\
\text { [136] }\end{array}$ & BRAF & I & $\begin{array}{l}150 \mathrm{mg} \text { twice } \\
\text { daily or } 100 \mathrm{mg} \\
\text { three times daily }\end{array}$ & 14 & 29 & 11.3 & $\begin{array}{l}\text { skin papillomas (57\%), } \\
\text { hyperkeratosis ( } 36 \%), \text { alopecia } \\
(29 \%) \text {, elevated lipase (7\%), } \\
\text { grade } 3 \text { elevated amylase ( } 7 \%) \text {, } \\
\text { grade } 3 \text { fatigue (7\%), grade } 3 \\
\text { febrile neutropenia (7\%), and } \\
\text { grade } 3 \text { cutaneous squamous } \\
\text { cell carcinoma (7\%) }\end{array}$ & None \\
\hline $\begin{array}{l}\text { Vemurafenib } \\
{[137]}\end{array}$ & BRAF & $\|$ & $\begin{array}{l}960 \mathrm{mg} \text { orally } \\
\text { twice daily }\end{array}$ & 51 & 35 & 15.6 & $\begin{array}{l}\text { squamous cell carcinoma of } \\
\text { the skin }(23.5 \%) \text {, lymphopenia } \\
(8 \%) \text {, and increased } \\
\text { y-glutamyl-transferase (8\%) }\end{array}$ & \\
\hline
\end{tabular}

tumors has been reviewed by Saji et al. [25, 26]. Activation of AKT leads to downstream activation of different proliferative targets including: forkhead family of transcription factor (FoxO), mammalian target of rapamycin (mTOR) and others [26].

Recent data, including the thyroid cancer gene atlas, suggests that other novel escape mechanisms may also exist, e.g. TKRs in other pathways have been found to be expressed in thyroid tumor cells, with evidence of downstream pro-proliferative actions [14, 27-29]. For example, studies on patient-derived thyroid tumors from patients with advanced cancer have demonstrated that a substantial percentage exhibit the increased presence of HER2/3 receptors as well as ALK rearrangements. These mutations tend to serve as tumoral escape mechanisms from the currently used MKIs through activating MEK the downstream effector of RAF [27] as depicted in Fig. 1. HER2/3 has been found to be capable of activating PI3k cascade as well (Fig. 1). In the light of these facts, a number of strategies using multiple pathways targeting agents are under study. 


\section{Upstream targeting of tumoral escape cascade}

\section{Targeting (ERBB-HER2/3)}

A novel line of investigation involves targeting proposed upstream elements relative to MAPK/PI3K. HER2 (ErbB2) and HER3 (ErbB3) are tyrosine kinase receptors and member of the Epidermal growth factor receptor (EGFR) family [27]. Their activation leads to downstream activation of both MAPK and PI3K cascade (Fig. 1). Preclinical data has shown that targeting these receptors by MKIs has represented an effective strategy, especially for breast cancer where these receptors are abundant. An escape mechanism identified in BRAFmutant cells treated by Vemurafenib, is an overexpression of HER $2 / 3$ receptors and subsequent activation of mTOR cascades and MAPK [30] (Fig. 1). Therefore, current clinical efforts are assessing the role of HER receptors targeting in advanced thyroid cancer. NCT01947023 is a phase I trial assessing Lapatinib (HER2/3 blocker) in combination with Dabrafenib (BRAF inhibitor) for patients with advanced DTC and its primary results were published in ASCO 2017. Investigators included 15 evaluable patients with BRAF V600 mutations, 13 patients had DTC and 2 had ATC, prior MKI therapy was administered in 9/15 patients. Dabrafenib was given to all patients as $150 \mathrm{mg}$ bid starting 2 weeks prior to Lapatinib. Doses of daily Lapatinib were escalated in a standard $3+3$ design at (1) $750 \mathrm{mg}$; (2) $1250 \mathrm{mg}$; (3) $1500 \mathrm{mg}$. The reported partial response rate is $60 \%$ with a median PFS of 15 months (range, 2$34+$ months). Only $1 / 15$ patients developed grade III treatment-related toxicity, while dose-limiting toxicities were reported in only 1 patient with ATC and were unlikely related to drugs [31]. In another trial, the panERBB Inhibitor Neratinib (NCT 03065387) is being assessed for its effect in advanced solid tumors harboring any HER mutation, including thyroid cancer.

\section{Targeting ALK translocations}

Recently, ALK gene translocations were identified in patient-derived thyroid cancer cells [14] . In contrast to different $A L K$ translocation fusions, identified in other tumor types, the $S T R N-A L K$ fusions encoding for striatin were identified in thyroid cancer cells [32]. These hybrid mutations are found in up to $4 \%$ of ATC and $9 \%$ of poor differentiated thyroid cancer [33] and lead to continuous activation of proliferating MAPK pathway through MEK activation [34] (Fig. 1). Two clinical reports describe the effect of selective ALK inhibitors in the setting of ATC. Godbert et al. reported in a case report the effect of Crizotinib (an ALK inhibitor that is FDA-approved for ALK positive non-small cell lung cancer) in a 71 year-old female with ALK-rearrangement ATC [35]. This patient with stage IV, T4/N1A disease failed the initial treatment of concomitant chemoradiotherapy postoperatively
(Cisplatin, Etoposide, and radiotherapy) with progression of metastatic pulmonary nodules. The second line chemotherapy of carboplatin and etoposide was administered with no clinical benefit after 3 cycles. Strikingly, as a last step approach, genetic profiling revealed ALK overexpression with intact EML4 gene. Based on this finding, Crizotinib (ALK inhibitor) was started and 3 months post-treatment, CT showed 90\% regression in pulmonary nodules (RECIST criteria) and exceptional ECOG (Eastern Cooperative Oncology Group) performance status [35]. NCT02289144 is the only recruiting clinical trial, so far, aiming to assess the role of Ceritinib in patients with advanced ATC with positive ALK abnormalities.

\section{Downstream targeting of tumoral escape cascade Targeting mTOR}

The growing knowledge of involvement of PI3K pathway in thyroid tumor cells pathogenesis and escape from conventional targeted therapy led to closer studying several components of this pathway. Among these components is mTOR (mammalian target of rapamycin), which when inhibited has led to cell proliferation suppression [36].

Two mTOR inhibitors have sufficiently favorable trial data that they have been approved by the FDA for clinical usage for other cancers: Temsirolimus in advanced renal carcinoma and Everolimus for advanced renal carcinoma, metastatic breast cancer, and progressive endocrine tumors of pancreatic origin (PNET) [36]. Given observed clinical benefits of these drugs, and the belief that mTOR activation is a therapeutic target in thyroid cancer [37], these agents are being tested in the setting of advanced thyroid cancer. Early results from Phase II thyroid cancer trials give reason for hope. For example, NCT01025453, a Phase II study assessing the effect of Temsirolimus with Sorafenib in RAI-R thyroid cancer patients [38]. Out of 37 patients, eight patients achieved partial response (PR), 21 had stable disease, while one patient developed progression and the remaining seven were un-evaluable. These results were independent from RAS or RAF mutation and reflect the importance of considering mTOR targeting as a promising approach for RAI-R and advanced thyroid cancer patients. The estimated completion date of this trial is December 2017 for final data collection and primary outcome measurement. In addition, NCT01141309, a Phase II Study evaluating the combination of Everolimus (mTOR inhibitor) and Sorafenib was presented at ASCO 2015 [39]. Out of 41 patients with different types of progressive thyroid cancers included, only 38 were evaluable for the primary endpoint of clinical benefit at the date of publishing the results. In this cohort, 21 patients (55\%) had PR, 14 patients (37\%) achieved stable disease (SD), 
and three patients (8\%) had progressive disease (PD). The subgroup and general toxicity assessment of this combination showed better response and less toxicity when compared to Sorafenib monotherapy, especially in the DTC subgroup.

NCT01263951 is an ongoing trial (enrolling at the time of this writing) testing the effect of this combination in DTC patients who progressed on Sorafenib therapy alone. Its preliminary results presented at ASCO 2015 showed remarkable reduction in Sorafenib-induced hand-foot syndrome (HFS) as a side effect, with SD as the best response achieved in most patients [40].

NCT02143726, an enrolling phase II study, assesses the efficacy and safety of Sorafenib with or without Everolimus in treating patients with advanced, RAI-R Hurthle cell thyroid cancer.

Finally, the abundance of PI3K/Akt/mTOR abnormalities in ATC spots this pathway as an attractive target for group of patients suffering from ATC [25]. NCT02289144 is a recruiting trial aiming to assess the effect Ribociclib (targeting Retinoblastoma (RB) mutation) and Everolimus (mTOR inhibitor) in metastatic $\mathrm{Rb}+\mathrm{ATC}$ patients. The rationale of targeting $\mathrm{Rb}$ in those patients is the abundance of intact RB in ATC patients [41]. However, the awaited results of this trial may suggest new treatment strategies for ATC patients since retinoblastoma gene is still not considered a therapeutic target in ATC patients.

\section{MEK targeting}

As mentioned earlier, ALK translocation and HER2/3 mutations are capable to induce their pro tumor proliferative effect through MEK, a downstream effector of MAPK pathway (Fig. 1) [42]. This fact has attracted several trials to assess the effect of MEK blockage regardless of underlying genetic or molecular mutation.

The results of the phase II trial of Selumetinib (MEK 1-2 inhibitor) [43] yielded a tolerable safety profile in RAI-R PTC patients. However, it is to be noted that the effect of Selumetinib on progression-free survival (PFS) was affected by BRAF mutation status; where BRAF V600E mutants had a longer median PFS compared with patients with BRAF wild-type (WT) tumors. This suggest a preliminary evidence of stratified beneficence of Selumetinib based on underlying genetic abnormalities. Therefore more clinical trials with larger patients cohorts are addressing the efficacy of this drug in order to provide more clear evidences. NCT01843062 is currently an ongoing phase III trial aiming to assess the efficacy of Selumetinib vs placebo in DTC patients.

Other MEK inhibitors are being also assessed in advanced thyroid cancers. The primary results of NCT02034110 assessing Efficacy of Dabrafenib (BRAF inhibitor) and Trametinib (MEK inhibitor) in 16 patients with BRAF V600E (ATC) were published in ASCO 2017. The overall response rate (ORR) was reported to be $69 \%$ (11/16 patients). This regimen showed a controversial safety profile with grade 3-4 toxicities occurring in $\leq 19 \%$ of patients. However all of these toxicities were manageable [44].

The controversial preliminary results of NCT01723202 showed that adding Trametinib to Dabrafenib did not result in statistical significance in PR, ORR, SD, PFS as compared to Dabrafenib alone in BRAF mutated PTC patients [45]. These contradicted results open the question if the concept of MEK inhibitionalone or the underlying tumoral phenotype is the reason behind these results. However, the final results of these trials and comparative analysis of MEK blocking effect in different thyroid tumor types will add more solid evidence.

\section{lodine Resensitization using different strategies including MKIs}

Radioactive iodine (RAI) is widely used in the treatment of advanced follicular cell-derived thyroid cancers, but downregulation of the sodium-iodide symporter gene (SLC5A5, more commonly known as NIS) leads to resistance or RAI-R disease [46]. A novel therapeutic strategy has been to pharmacologically induce re-expression of NIS, i.e. "redifferentiating" the cells such that they can be treated with radioiodine.

In this regard, in vitro studies showed that Retinoids (Vitamin A-derived retinoic acids) are able to induce thyroid tumors redifferentiating effects like induction of 5 '-deiodinase [47], increased expression of NIS mRNA [48], and increased thyroglobulin level ( $\mathrm{Tg})$, known to be lost in de-differentiated thyroid cancers [47]. Several clinical studies followed that principle for inducing RAI resensitization [37, 49-52]. The results of these studies indeed showed that retinoic acid therapy could, to a certain degree, induce RAI reuptake. Despite that finding, a true clinical beneficence in controlling underlying thyroid tumors has not been widely demonstrated, rendering the clinical application of retinoids in daily practice a doomed option.

A related line of investigation has examined whether Pax-8/PPAR $\gamma$ agonists might, in theory, upregulate NIS in RAI-R tumors. Based on pre-clinical data positively correlating Pax-8 (Paired box-8) and NIS promotor activity [53], along with the observation that PAX8-PPAR $\gamma$ translocations are present in $35 \%$ of FTC. Accordingly, a phase II study demonstrated that the Pax-8-PPARy agonist Rosiglitazone (4 mg daily for 1 week, then $8 \mathrm{mg}$ daily for 7 weeks) was associated with improved I-131 uptake in 4 out of 10 subjects [54].

Recently, the observation that constitutive activation of MAPK signaling causes transcriptional inhibition of thyroid hormone biosynthesis genes including NIS has 
led to the investigation of certain selective MAPK blocking agents as RAI resensitizer agents. [55].

In a phase II 'proof of concept' trial, Selumetinib (a MEK inhibitor) increased iodine uptake in 12 of 20 patients (quantitative $\mathrm{I}^{124}$ uptake). Eight of the 12 patients reached the dosimetry threshold for RAI therapy [56]. The genetic subgroup analysis showed that all patients with RAS-mutated DTC (5 patients) responded to Selumetinib, while only four out of nine patients with BRAF mutation had a response. This difference could be attributed to either the effect of BRAF mutation on normal thyroid gene expression or to BRAFinduced TGFB (Transforming Growth Factor B) signaling, which represses NIS expression [57]. Two ongoing trials, NCT01843062 and NCT02393690, both placebo-controlled trials with Selumetinib in locallyadvanced, recurrent, or metastatic thyroid cancer will add more data to this existing pool of evidence, as well as a similar trial with the MEK inhibitor Trametinib, (NCT02152995).

Dabrafenib (BRAF inhibitor) restored RAI uptake in PTC advanced patients [58]. Out of 10 selected patients,
$60 \%(n=6)$ showed increase RAI-131 uptake with $2 / 6$ having partial response.

\section{Immunotherapy in thyroid cancer}

Several preclinical studies suggested promise for immunotherapy in the treatment of advanced follicular cell derived cancer as well as for MTC. While this general approach has been less developed in terms of clinical trial data than the MKI studies, there are several ongoing immunotherapy trials with clinical promise.

\section{Changes in immune system relevant to thyroid cancer}

Several models have been developed to explain tumor immunosurveillance $[59,60]$. These models divide the immune system's response to cancer formation into 3 distinct phases: elimination, equilibrium, and escape. In the elimination phase, immune system can recognize and eliminate transformed cells. During the equilibrium phase, there is a generation of tumor cell variants with increased capacity of evading immunosurveillance due to the initial pressure by the immune system (Fig. 2).

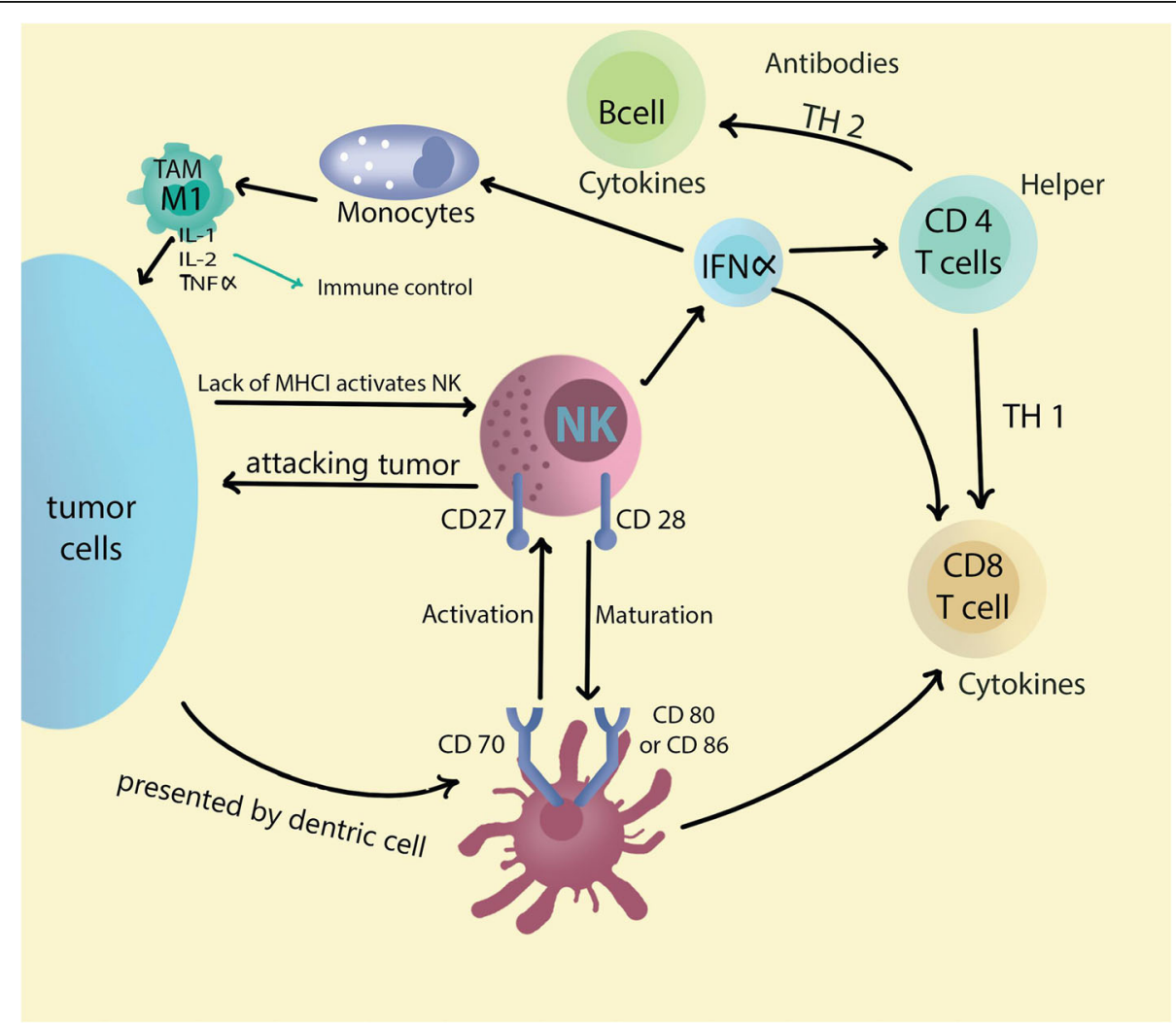

Fig. 2 Tumor immune surveillance and host early response to tumor microenvironment: The lack of $\mathrm{MHC}$ I on tumor cells activates Natural killer cells. Dendritic cells present tumor antigens to cytotoxic T cells which exhibit a cytotoxic activity on dividing malignant cells. Note in tumor surveillance phase that tumor associated macrophages (TAM) present in tumor microenvironment are of anti-tumoral M1 phenotype and also the expressed cytokines in the medium are of immune stimulatory type 
During the escape phase (Fig. 3), the emerging and evolved neoplastic cell variants are finally able to escape the immune system, leading to tumor growth and clinically evident disease.

To leverage the natural immune response and restore its elimination ability of thyroid tumor cells, crucial understanding of the tumor microenvironment and its complex interaction with the immune system is required. In Table 3, we highlight observations regarding specific patterns in tumor-associated immune cells within the thyroid cancer microenvironment, and how this might be used in anticancer future therapies.

\section{Strategies for thyroid cancer immunotherapies}

Many oncologic trials have focused on developing immunomodulating therapies to restore the functional ability of different immune cells against neoplastic cellsand, with promising results in several tumor types, including lung cancer, melanoma, and colon cancer [61, 62]. Recent efforts and advances in translational research led to proposing several strategies for immunomodulation in thyroid cancer and they will be reviewed here.

\section{Inhibiting recruitment of tumor associated macrophages (TAM)}

It was found that thyroid tumoral tissues expressed increased levels of CSF-1 and CCL-2 in human tissue samples [63]. These molecules are known to be chemoattractants to TAMs. Since TAM represent more than $50 \%$ of anaplastic thyroid cancer volume, and to a lesser extent that of advanced DTC, blocking and targeting CCL-2/CCR2 and CSF-1/ CSF-1R pathways represents a promising approach (Fig. 3). This approach proposes not only inhibiting the recruitment of protumor M2 phenotype TAMs, but also their repolarization into the M1 antitumor phenotype [64-66]. Therefore, the concept of depleting and repolarizing TAM to enhance anti-tumor immune response is the subject of many ongoing trials. In NCT01346358, CSF-1R antibody LY3022855 (also known as IMC-CS4) is tested against advanced solid tumors. NCT01525602 is recruiting

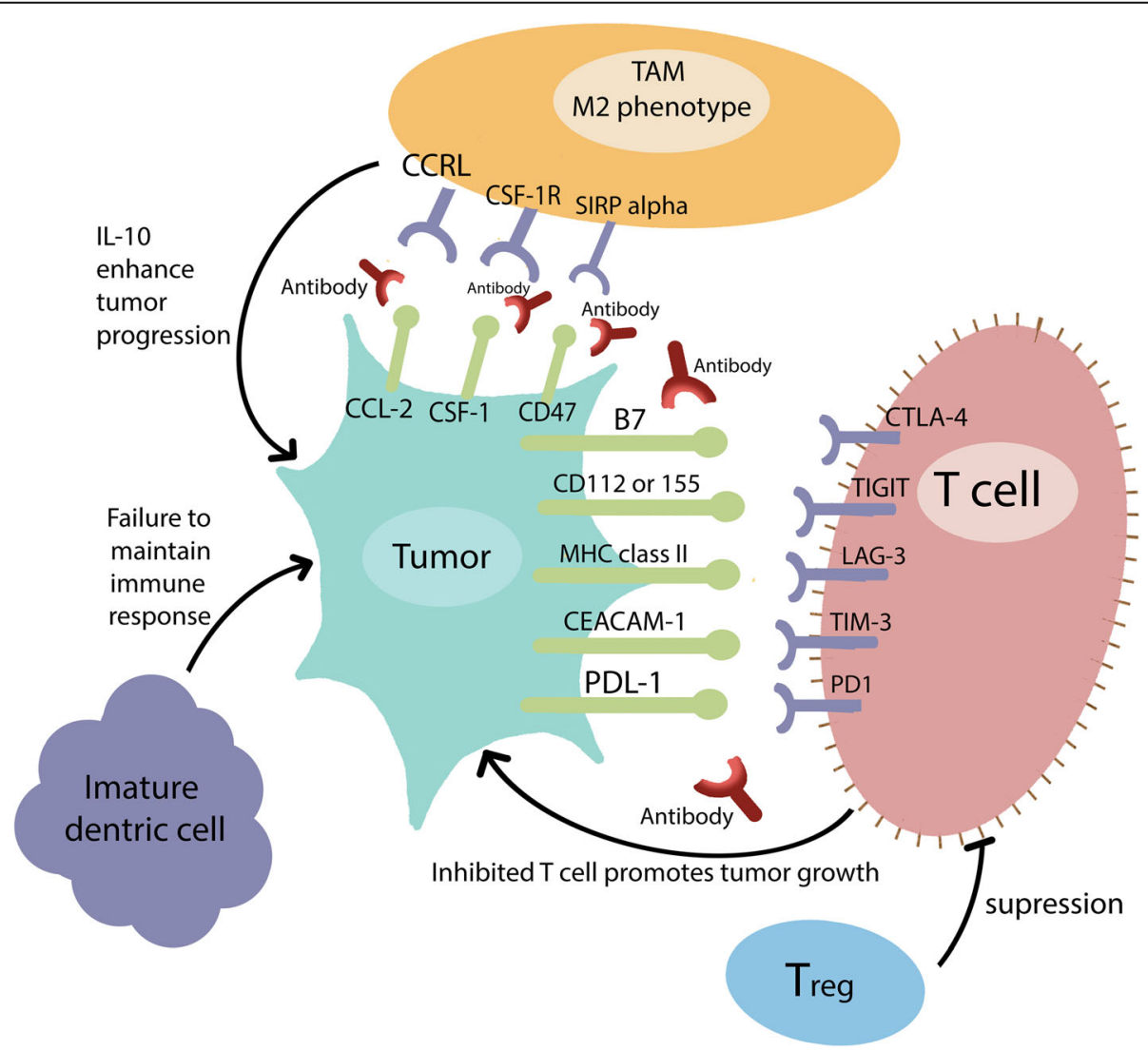

Fig. 3 Tumor immune escape phase: The increased expression of checkpoint inhibitors on T cells surface and their corresponding ligands on tumor cells lead to remarkable inhibition of host immune response. Presence of regulatory T cells (Treg) and M2 phenotype TAM (tumor associated macrophages) in tumor microenvironment contribute to tumor progression through T cell suppression by the first and pro-tumor IL-10 secretion by the second 
Table 3 Patterns in tumor-associated immune cells within the thyroid cancer microenvironment

\begin{tabular}{|c|c|}
\hline $\begin{array}{l}\text { Immune } \\
\text { Component (Cell type) }\end{array}$ & Studies in Thyroid Cancer (with references) \\
\hline B cells & $\begin{array}{l}\text { Antithyroid antibodies (secreted by B cells) } \\
\text { are present in } 18-40 \% \text { of patients with PTC, } \\
39 \% \text { in those with benign thyroid nodules, } \\
\text { and } 10-14 \% \text { of general population [138-142] }\end{array}$ \\
\hline
\end{tabular}

Mast Cells

T cells

Natural Killer cells (NK)

\section{Patients with aggressive ATC or advanced and
metastatic thyroid cancers were reported to have low peripheral blood NK cells in comparison to patients with benign lesions or other control patients. Introduction of IL-12 (an NK activating cytokine) in a murine model of BRAF-mutated thyroid cancer was helpful in restoring the tumor immune elimination properties. -Also, it is to be noted that NK cells could lyse anaplastic thyroid cells ex-vivo. It is hoped that these anti-tumoral activities of NK cells could be used in thyroid cancer immunotherapy [150-156].}

Tumor associated macrophages (TAM)
These cells belong to the monocytemacrophage lineage. There are two phenotypes of TAMs: M1 expressing IL-1, IL-12, and TNF-a, contributing to immune control over tumors; and $\mathrm{M} 2$ expressing IL-10 and CD163, promoting tumor progression and inhibition of tumor immune elimination. It was concluded that in PTC and poorly differentiated thyroid cancer, the density and presence of M2 TAMs correlated with tumor invasion and decreased survival. In anaplastic tumors, the TAMs form greater than $50 \%$ of tumor mass [157-159].
Table 3 Patterns in tumor-associated immune cells within the thyroid cancer microenvironment (Continued)

\begin{tabular}{|c|c|}
\hline $\begin{array}{l}\text { Immune } \\
\text { Component (Cell type) }\end{array}$ & Studies in Thyroid Cancer (with references) \\
\hline Dendritic cells & $\begin{array}{l}\text { Immature dendritic cells expressing CD1a or } \\
\text { S100 were found in PTC human tissue samples, } \\
\text { and these cells failed to maintain an immune } \\
\text { response to thyroid cancer cells [160-162]. A } \\
\text { relation between TAMs and inability of dendritic } \\
\text { cells to mature and present tumoral antigens } \\
\text { has been proposed [163]. Such relation } \\
\text { suggests that targeting inhibitory TAMs could } \\
\text { enhance dendritic cells differentiation. However, } \\
\text { this concept remains yet to be validated in } \\
\text { more pre-clinical studies as well as clinical trials. }\end{array}$ \\
\hline
\end{tabular}

patients with advanced solid tumors to test the effect of CSF-1R inhibitor (PLX3397) plus paclitaxel. Both studies include a cohort of thyroid patients.

\section{Identification of tumor specific antigen and tumor neoantigens}

Creating a cancer vaccine was recently the purpose of the cancer "Moonshot 2020" project [67]. Identification of thyroid tumor specific or neoantigens could pave the path towards creating a successful vaccine for tumor specific dendritic cells and thyroid cancer specific $\mathrm{T}$ cells. Tumor-associated antigens (melanoma antigen encoding genes [MAGE], mucin-1 antigen [MUC1], and proto-oncogene c-MET) can be expressed along with thyroid specific proteins (thyroglobulin and thyroid peroxidase) in DTC [68-70].

Several studies showed that the burden of genetic alteration and thyroid tumor neo-antigen is more prevalent in poorly differentiated and anaplastic tumors than in early differentiated stages [71]. Dendritic cell (DC) vaccines targeting the carcinoembryonic antigen (CEA), which is commonly expressed in MTC, have shown some clinical promise in these patients [72]. In this study, mature DCs, generated from peripheral blood monocytes and loaded with calcitonin and carcinoembryonic antigen (CEA) were injected in a cohort of 7 patients. Calcitonin and CEA were remarkably decreased in 3/7 patients with one of these three showing complete regression of metastatic hepatic and pulmonary nodules [72].

Other efforts of clinical targeting specific thyroid antigens is also under investigation; NCT01856920 is testing GI-6207, a vaccine made from baker's yeast targeting the CEA in patients with MTC. NCT02239861 is recruiting patients to test specific adoptive cytotoxic T cells targeting several tumor antigens (NY-ESO-1, MAGEA4, PRAME, survivin, and SSX) in patients with advanced solid tumors, including thyroid cancer patients. 


\section{Blocking and inhibiting immune checkpoints}

The recent identification of blocking antibodies of CTLA-4 and PD-1 to their corresponding ligands (CD80/86 and PD-L1/PD-L2 respectively) represented a new hope in cancer immunotherapy [73]. Blocking these inhibitory pathways enhance the effector $\mathrm{T}$ cells and inhibit the regulatory suppressor cells (Fig. 4). Antibodies to CTLA-4 like Ipilimumab and Tremelimumab, and antibodies to PD-1 like Pembrolizumab and Novilumab, were approved by the FDA for treatment of several types of cancers including melanoma, non-small cell lung cancer, and renal carcinoma [73]. The increased frequency of PD-1(+) T cell in thyroid tumor-involved lymph nodes in PTC patients suggests potential utility for these checkpoint inhibitors in advanced thyroid cancers [74]. NCT02054806 is testing Pembrolizumab effect as monotherapy in advanced solid tumor patients including a cohort of thyroid cancer patients. Early results published in ASCO 2017 included a cohort of 22 thyroid patients in which 18 were radioactive iodine refractory; 7 received prior Sorafenib; and 1 received prior lenvatinib. Investigators reported $2 / 22$ patients with $\mathrm{PR}, 12 / 22$ patients with stable disease while 18/22 developed treatment related side effects most of them of grade 2-3. However, no patients discontinued or died from treatment adverse effects [75].

Dual targeting of the immune system in thyroid tumor microenvironment could, in theory, maximize the clinical benefits. This approach has been adopted by several trials: NCT02452424 is testing CSF-1R inhibitor (PLX3397) plus PD-1 inhibitor (Pembrolizumab) against advanced melanoma and other solid tumors, including thyroid. NCT02718911 is testing another CSF-1R inhibitor (LY3022855) plus Tremelimumab or Durvalumab (PD-1 inhibitors) in solid tumors.

\section{Restoring the tumor phagocytic ability of TAM and enhancing tumor antigen presentation}

Generally, most cancer cells, including thyroid cancers, were found to express an inhibitory receptor coined CD47, whose ligand is TAM signal-regulatory protein $\alpha$ (SIRP $\alpha)$. This receptor-ligand interaction leads to inhibiting the phagocytic ability of TAM, and impaired tumor antigen presentation by dendritic cells. In mouse models, blocking SIRP $\alpha / C D 47$ was successful in inducing tumor regression. Therefore, blocking CD47 by monoclonal antibodies or targeting SIRP $\alpha$, represents an approach to reverse the immunoinhibitory effect of this pathway [76-78]. This concept was proven preclinically, where blocking CD47 in human thyroid cancer cell lines showed apoptotic effects [79]. However, clinical trials assessing CD47 targeting are needed to assess the clinical efficacy of this approach.

\section{MKIs and immunotherapy}

Recent data showing a role for kinase inhibitors in immune modulation brings the promise that perhaps both strategies can be utilized simultaneously to achieve better responses in advanced thyroid cancer. Regulatory $\mathrm{T}$ cells express VEGFR-2, and both VEGF-A and BRAF$V 600 E$ are associated with upregulation of PD-1 expression, leading to inhibition of cytotoxic T cells [80-82].

Therefore, currently available MKIs could potentially reverse the inhibitory effects of pathologic kinase activities on the immune system.

For example, in an ex-vivo studies, Sorafenib reduced the number of immune inhibitory regulatory $\mathrm{T}$ cells (Treg) and hence, potentiating the immune response $[83,84]$. Several clinical trials are currently assessing the effect of combining MKIs with immune therapy for refractory and advanced tumors. For example, Sulfatinib is

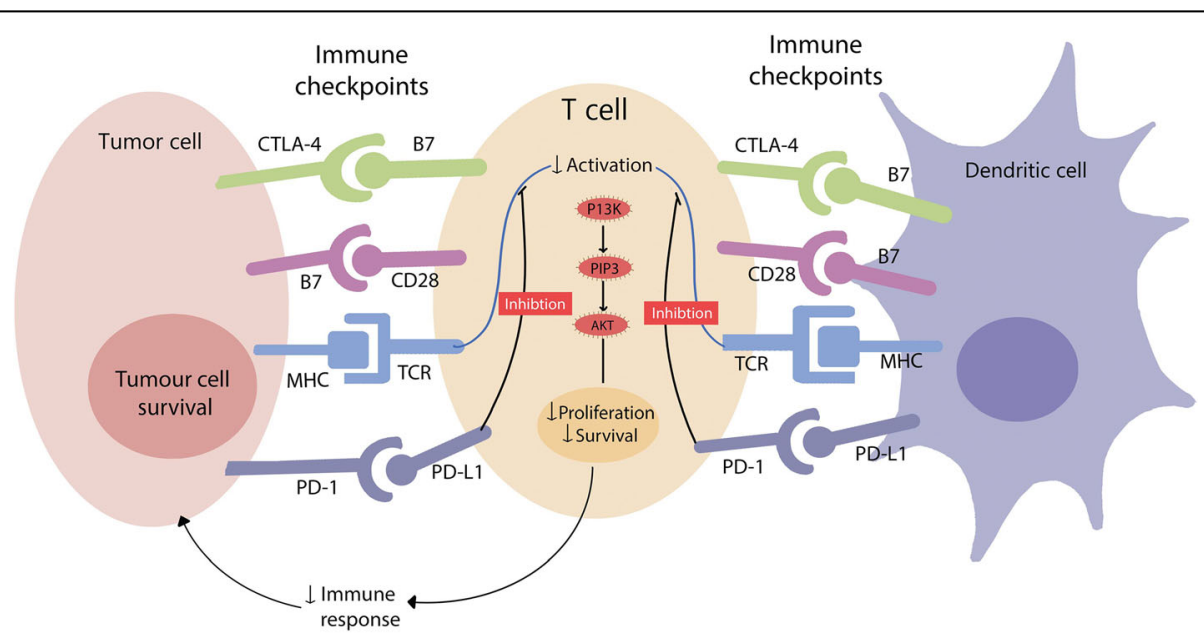

Fig. 4 Immune checkpoints and their proposed mechanism of action in T cells: Several immune checkpoints are overexpressed on T cell surface in thyroid tumor microenvironment and their corresponding ligands on tumor cells or immature dendritic cells. Interaction of receptors and ligands lead to inhibition of the AKT pathway inside T cells and subsequently inhibition of T cell proliferation and division 
an oral MKI targeting VEGFR, FGFR-1, and CSF1R, hence, potentially having a dual role in targeting angiogenesis and promoting immunomodulation. The first primary results of NCT02614495, an open label, two cohort, phase I and II trial assessing the role of Sulfatinib in advanced MTC and RAI-R DTC, were presented at ASCO 2017. In this trial, 18 patients (MTC: 6, DTC: 12) were assigned to Sulfatinib $300 \mathrm{mg}$ once daily. There were a total of 4 confirmed partial responses, 3 in the DTC cohort and 1 in the MTC cohort; all other patients achieved stable disease. Treatment side effects were mostly grade 3-4 with no grade 5 toxicity observed. These side effects resulted in dose interruption in 11 patients and dose reduction in 5 patients. Combination therapy is being explored as well, for example NCT02501096 (phase IB/II trial) is currently recruiting patients with solid tumors (including thyroid cancer) to assess the maximum tolerated dose (MTD) for Lenvatinib in combination with Pembrolizumab during phase IB of the trial, and a subsequent expansion phase II trial will evaluate the safety and efficacy of this combination. NCT01988896 is assessing the effect of combining the PDL-1 inhibitor Atezolizumab, plus the mitogenactivated protein kinase (MAPK) inhibitor, Cobimetinib, in locally advanced or metastatic solid tumors. Other trials combining MKIs with immunotherapy that may redefine systemic therapy for advanced thyroid cancer are listed in Table 4.

\section{Future directions for scientific and clinical community}

Based on current evidences and preliminary results of clinical trials assessing new treatment strategies, clustering patients with advanced thyroid cancers who failed conventional treatment options, according to their underlying molecular profile involved in disease development, will definitely help optimizing treatment decisions in clinical scenarios. This fact can be attributed to the widely varying molecular nature of different escape mechanisms from drugs targeting MAPK. The awaited clinical trials mentioned in this review (Additional file 1: Table S1) will definitely help implement new treatment strategies for these patients.

Also, there is clearly much work to be done to identify novel therapeutic targets and to develop strategies for treating advanced thyroid cancer. Pre-clinical data suggests a number of areas that could be developed in the coming years. For example, Histone Deacetylase Inhibitors (HDACIs) have been shown to increase expression of tumor suppressor genes in in vitro models of MTC [85-88]. Enthusiasm is tempered by two recent trials using the HDACI Valproic Acid in RAI-R DTC and ATC with negative results $[89,90]$, and yet other HDACIs may have potential based on very recent pre-clinical
Table 4 Immunotherapy trials addressing thyroid cancer

\begin{tabular}{|c|c|c|}
\hline $\begin{array}{l}\text { Immunological } \\
\text { Target }\end{array}$ & Trial & Brief description \\
\hline TAM & NCT01346358 & $\begin{array}{l}\text { CSF-1R antibody LY3022855 (also } \\
\text { known as IMC-CS4) is tested in } \\
\text { advanced solid tumors, including } \\
\text { thyroid cancer }\end{array}$ \\
\hline TAM & NCT01525602 & $\begin{array}{l}\text { Testing the effect of CSF-1R inhibitor } \\
\text { (PLX3397) plus paclitaxel in patients } \\
\text { with advanced solid tumors, including } \\
\text { thyroid cancer }\end{array}$ \\
\hline Dendritic cells & NCT01856920 & $\begin{array}{l}\text { Testing Gl-6207, a vaccine made from } \\
\text { baker's yeast, targeting the CEA in } \\
\text { patients with MTC }\end{array}$ \\
\hline Dendritic cells & NCT02239861 & $\begin{array}{l}\text { Testing specific adoptive cytotoxic T } \\
\text { cells targeting several tumor antigens } \\
\text { (NY-ESO-1, MAGEA4, PRAME, survivin, } \\
\text { and SSX) in patients with advanced } \\
\text { solid tumors, including thyroid cancer } \\
\text { patients }\end{array}$ \\
\hline T cells & NCT02054806 & $\begin{array}{l}\text { Testing Pembrolizumab effect as } \\
\text { monotherapy in advanced solid tumor } \\
\text { patients, including a cohort of thyroid } \\
\text { cancer patients }\end{array}$ \\
\hline TAM & NCT02452424 & $\begin{array}{l}\text { Testing CSF-1R inhibitor (PLX3397) plus } \\
\text { PD-1 inhibitor (Pembrolizumab) against } \\
\text { advanced melanoma and other solid } \\
\text { tumors, including thyroid }\end{array}$ \\
\hline \multirow[t]{2}{*}{ TAM } & NCT02718911 & $\begin{array}{l}\text { Testing another CSF-1R inhibitor } \\
\text { (LY3022855) plus Tremelimumab or } \\
\text { Durvalumab (PD-1 inhibitors) in solid } \\
\text { tumors }\end{array}$ \\
\hline & NCT02614495 & $\begin{array}{l}\text { Open label - two cohorts - phase I, ॥ } \\
\text { trial assessing the role of Sulfatinib in } \\
\text { advanced MTC and RAI-R DTC }\end{array}$ \\
\hline T cells & NCT02501096 & $\begin{array}{l}\text { Phase IB/II trial, currently recruiting } \\
\text { patients with solid tumors to assess the } \\
\text { maximum tolerated dose (MTD) for } \\
\text { Lenvatinib in combination with } \\
\text { Pembrolizumab during phase IB of the } \\
\text { trial. A subsequent expansion phase II } \\
\text { trial will evaluate the safety and } \\
\text { efficacy of this combination }\end{array}$ \\
\hline T cells & NCT01988896 & $\begin{array}{l}\text { Testing the effect of combining the } \\
\text { PDL-1 inhibitor Atezolizumab, plus the } \\
\text { mitogen-activated protein kinase } \\
\text { (MAPK) inhibitor, Cobimetinib, in } \\
\text { Locally Advanced or Metastatic Solid } \\
\text { Tumors }\end{array}$ \\
\hline T cells & NCT01656642 & $\begin{array}{l}\text { Phase IB trial investigating PD-L1 } \\
\text { antibody Atezolizumab plus mutant } \\
\text { BRAF inhibitor Vemurafenib for patients } \\
\text { with BRAFV600 mutation-positive } \\
\text { metastatic melanoma (even though } \\
\text { this trial has no thyroid patients, its } \\
\text { results will help in designing future } \\
\text { thyroid trials using such a combination } \\
\text { based on pharmacodynamics and } \\
\text { kinetics of this study) }\end{array}$ \\
\hline
\end{tabular}

data,; for example CUDC-907, a dual inhibitor of HDACs and PI3k pathway, showing apoptotic effects in thyroid cancer cell lines in vitro and significant 
inhibition of growth and metastasis in a metastatic mouse model [91].

Another area to be developed is in the identification of biomarkers: a biomarker predicting the likelihood of clinical beneficence from targeted therapy is still lacking. One promising approach is looking at miRNAs, with certain expression patterns possibly providing a signature related to different clinicopathological features of thyroid cancer [92]. Finally, investigators are using kinome profiling, studying kinase complement of the human genome, combined with other transcriptional phosphoproteomics studies, to look for new treatment targets and strategies enhancing the currently available MKIs. One recent report identified SRC kinases as targets for invasive thyroid tumors using kinase phosphorylation assay [93]. Another report, using global phosphoproteomics analysis, identified CK2 (Caseine Kinsase 2) as a survival mechanism after BRAF-MEK signaling blockade [94]. These markers might be developed as tools to monitor response to different MKIs therapies targeting MAPK. An interesting report by Martinez et al. identified new molecular targets using mass spectrometry proteomics on a large scale [95]; in this study, TGF $\beta$-induced protein ig-h3 (TGFBI) was found to be overexpressed in FTC. PTC samples, in comparison to FTC and normal tissue samples, was found to overexpress the extracellular protein Decorin, Tenascin, and AGR-2 [95]. These findings can provide future targets for new therapeutics.

\section{Conclusion}

Thyroid cancer patients with advanced disease still do not have adequate treatment options, but the immediate and long-term future of therapy in this area looks bright. As research leads to a better understanding of underlying molecular changes in these patients, it should become increasingly possible to offer individualized, targeted therapy in their treatment protocols. With a number of MKIs being studied that can target the key pathways and escape mechanisms driving advanced thyroid cancer, and with the dawn of the age of immunotherapy, it can be hoped and perhaps even expected that soon novel therapeutics arise offering better long-term survival for these patients.

\section{Additional file}

Additional file 1: Table S1. Ongoing clinical trials mentioned. (DOCX $16 \mathrm{~kb}$ )

\section{Acknowledgements}

This study is Supported by the grant for US-egyptian research cooperative grant cycle 17 STDF144. We would like to thank Nardine Hany for her help in designing the figures for that article.
Authors' contributions

GN did the literature search and writing. GN, MM, BK, and WA did the concept design and editing for review. All authors reviewed and agreed to the final version of the manuscript.

\section{Competing interests}

The authors declare that they have no competing interests.

\section{Publisher's Note}

Springer Nature remains neutral with regard to jurisdictional claims in published maps and institutional affiliations.

\section{Author details \\ 'Department of Radiation Oncology, Harvard Medical School, Massachusetts General Hospital, 55 Fruit St, Boston, MA 02114, USA. ${ }^{2}$ Alexandria Comprehensive Cancer center, Alexandria, Egypt. ${ }^{3}$ Department of Endocrinology, Rush University, 1900 W Polk St, Room 801, Chicago, IL, USA. ${ }^{4}$ Department of Endocrinology, Thyroid Cancer Program, Rush University, Jelke Building, Room 604, 1735 W Harrison St, Chicago, IL 60612, UK. \\ ${ }^{5}$ University Of Alexandria, Clinical oncology department, Alexandria, Egypt. ${ }^{6}$ Department of Radiation Oncology, University of Alabama at Birmingham, 1720 2nd Ave S, Birmingham, AL 35294, UK.}

Received: 19 September 2017 Accepted: 1 February 2018 Published online: 19 February 2018

\section{References}

1. Chen AY, Jemal A, Ward EM. Increasing incidence of differentiated thyroid cancer in the United States, 1988-2005. Cancer. 2009;115(16):3801-7.

2. Pellegriti $\mathrm{G}$, et al. Worldwide increasing incidence of thyroid cancer: update on epidemiology and risk factors. J Cancer Epidemiol. 2013;2013:10.

3. Liska J, et al. Thyroid tumors: histological classification and genetic factors involved in the development of thyroid cancer. Endocr Regul. 2005;39(3):73-83.

4. Xu B, Ghossein R. Genomic landscape of poorly differentiated and anaplastic thyroid carcinoma. Endocr Pathol. 2016;27(3):205-12.

5. Nikiforov YE, Nikiforova MN. Molecular genetics and diagnosis of thyroid cancer. Nat Rev Endocrinol. 2011;7(10):569-80.

6. Hadoux J, et al. Management of advanced medullary thyroid cancer. Lancet Diabetes Endocrinol. 2016;4(1):64-71.

7. Spitzweg C, et al. Advanced radioiodine-refractory differentiated thyroid cancer: the sodium iodide symporter and other emerging therapeutic targets. Lancet Diabetes Endocrinol. 2014;2(10):830-42.

8. Cabanillas ME, et al. Anaplastic thyroid carcinoma: treatment in the age of molecular targeted therapy. J Oncol Pract. 2016;12(6):511-8.

9. American Cancer Society. Cancer Facts \& Figures. Atlanta: G.A.C.S; 2017.

10. Baudino TA. Targeted cancer therapy: the next generation of cancer treatment. Curr Drug Discov Technol. 2015;12(1):3-20.

11. Bikas A, et al. Targeted therapies in thyroid cancer: an extensive review of the literature. Expert Rev Clin Pharmacol. 2016:1-15.

12. Widakowich $\mathrm{C}$, et al. Review: side effects of approved molecular targeted therapies in solid cancers. Oncologist. 2007;12(12):1443-55.

13. Nikiforov YE. Thyroid carcinoma: molecular pathways and therapeutic targets. Mod Pathol. 2008;21(Suppl 2):S37-43.

14. Agrawal N, et al. Integrated genomic characterization of papillary thyroid carcinoma. Cell. 2014;159(3):676-90

15. Cooper DS, et al. Revised American Thyroid Association management guidelines for patients with thyroid nodules and differentiated thyroid cancer. Thyroid. 2009;19(11):1167-214.

16. Haugen BR, et al. 2015 American Thyroid Association management guidelines for adult patients with thyroid nodules and differentiated thyroid cancer: the American Thyroid Association guidelines task force on thyroid nodules and differentiated thyroid cancer. Thyroid. 2016;26(1):1-133.

17. Bernet $V$, Smallridge R. New therapeutic options for advanced forms of thyroid cancer. Expert Opin Emerg Drugs. 2014;19(2):225-41.

18. Carneiro RM, et al. Targeted therapies in advanced differentiated thyroid cancer. Cancer Treat Rev. 2015;41(8):690-8.

19. Viola D, et al. Treatment of advanced thyroid cancer with targeted therapies: ten years of experience. Endocr Relat Cancer. 2016;23(4):R185-205.

20. Bible KC, Ryder M. Evolving molecularly targeted therapies for advancedstage thyroid cancers. Nat Rev Clin Oncol. 2016;13(7):403-16. 
21. Brose MS, et al. Effect of age on the efficacy and safety of Lenvatinib in radioiodine-refractory differentiated thyroid cancer in the phase III SELECT trial. J Clin Oncol. 2017;35(23):2692-9.

22. Lo RS. Receptor tyrosine kinases in cancer escape from BRAF inhibitors. Cell Res. 2012;22(6):945-7.

23. Rexer $\mathrm{BN}$, Engelman JA, Arteaga $\mathrm{CL}$. Overcoming resistance to tyrosine kinase inhibitors: lessons learned from cancer cells treated with EGFR antagonists. Cell Cycle. 2009;8(1):18-22.

24. Sennino B, DM MD. Controlling escape from angiogenesis inhibitors. Nat Rev Cancer. 2012;12(10):699-709.

25. Xing M. Genetic alterations in the Phosphatidylinositol-3 kinase/Akt pathway in thyroid cancer. Thyroid. 2010;20(7):697-706.

26. Saji M, Ringel MD. The PI3K-AKT-mTOR pathway in initiation and progression of thyroid tumors. Mol Cell Endocrinol. 2010;321(1):20-8.

27. Luo M, Fu LW. Redundant kinase activation and resistance of EGFR-tyrosine kinase inhibitors. Am J Cancer Res. 2014;4(6):608-28.

28. Ruggeri RM, et al. HER2 analysis in sporadic thyroid cancer of follicular cell origin. Int J Mol Sci. 2016;17(12)

29. Chou A, et al. A detailed clinicopathologic study of ALK-translocated papillary thyroid carcinoma. Am J Surg Pathol. 2015;39(5):652-9.

30. Montero-Conde $\mathrm{C}$, et al. Relief of feedback inhibition of HER3 transcription by RAF and MEK inhibitors attenuates their antitumor effects in BRAF mutant thyroid carcinomas. Cancer Discov. 2013;3(5):520-33.

31. Sherman EJ, Ho AL, Baxi SS, Dunn L, Korte SH, et al. Combination of dabrafenib (DAB). J Clin Oncol. 2017;35(15 suppl):6085.

32. Kelly LM, et al. Identification of the transforming STRN-ALK fusion as a potential therapeutic target in the aggressive forms of thyroid cancer. Proc Natl Acad Sci U S A. 2014;111(11):4233-8.

33. Murugan AK, Xing M. Anaplastic thyroid Cancers Harbor novel oncogenic mutations of the ALK gene. Cancer Res. 2011;71(13):4403-11.

34. Roberts PJ, Der CJ. Targeting the Raf-MEK-ERK mitogen-activated protein kinase cascade for the treatment of cancer. Oncogene. 0000, 26(22):3291-310.

35. Godbert $Y$, et al. Remarkable response to Crizotinib in woman with anaplastic lymphoma kinase-rearranged anaplastic thyroid carcinoma. J Clin Oncol. 2015;33(20):e84-7.

36. Pópulo H, Lopes JM, Soares P. The mTOR Signalling pathway in human cancer. Int J Mol Sci. 2012;13(2):1886-918.

37. Souza EC, Ferreira AC, Carvalho DP. The mTOR protein as a target in thyroid cancer. Expert Opin Ther Targets. 2011;15(9):1099-112.

38. EJ Sherman, AL Ho, MG. Fury, SS. Baxi, S Haque, SH Korte, S Smith-Marrone, H Xiao, RA Ghossein, JA. Fagin, DG. Pfister. A phase II study of temsirolimus/ sorafenib in patients with radioactive iodine (RAl)-refractory thyroid carcinoma. asco meeting 2012. abstract\#5514.

39. EJ Sherman, AL Ho, MG. Fury, SS. Baxi, L Dunn, JS Lee, BL Lipson, DG. Pfister, Combination of everolimus and sorafenib in the treatment of thyroid cancer: Update on phase II study. ASCO 2015. Abstract\#6069.

40. M.S. Brose, A.B. Cohen, M. Yarchoan, A. B. Cohen, K. Harlacker, N.A. Dyanick, Z.A. Posey, R. Makani, P. Prajapati, L.M. Zifchak, C. Grande, C.M. Squillante. A phase II study of everolimus (E) and sorafenib (S) in patients (PTS) with metastatic differentiated thyroid cancer who have progressed on sorafenib alone. ASCO 2015. Abstract\# 6072.

41. Anwar F, et al. Retinoblastoma Expression in Thyroid Neoplasms. Mod Pathol. 13(5):562-9.

42. Roberts PJ, Der CJ. Targeting the Raf-MEK-ERK mitogen-activated protein kinase cascade for the treatment of cancer. Oncogene. 2007;26(22):3291-310.

43. Hayes DN, et al. Phase II efficacy and pharmacogenomic study of Selumetinib (AZD6244; ARRY-142886) in iodine-131 refractory papillary thyroid carcinoma with or without follicular elements. Clin Cancer Res. 2012;18(7):2056-65.

44. Subbiah V, Kreitman RJ, Wainberg ZA, Cho JY, Schellens JHM, et al. Efficacy of dabrafenib (D) and trametinib (T) in patients (pts) with BRAF V600E-mutated anaplastic thyroid cancer (ATC). J Clin Oncol. 2017;35(15 suppl):6023.

45. Shah MH, Wirth L, Wirth LJ, Daniels GA, De Souza JA, et al. Results of randomized phase II trial of dabrafenib versus dabrafenib plus trametinib in BRAF-mutated papillary thyroid carcinoma. J Clin Oncol. 2017;35(15 suppl):6022.

46. Kogai T, Brent GA. The sodium iodide symporter (NIS): regulation and approaches to targeting for cancer therapeutics. Pharmacol Ther. 2012; 135(3):355-70.

47. Van Herle AJ, et al. Effects of 13 cis-retinoic acid on growth and differentiation of human follicular carcinoma cells (UCLA RO 82 W-1) in vitro. J Clin Endocrinol Metab. 1990;71(3):755-63.
48. Schmutzler $C$, et al. Retinoic acid increases sodium/iodide symporter mRNA levels in human thyroid cancer cell lines and suppresses expression of functional symporter in nontransformed FRTL-5 rat thyroid cells. Biochem Biophys Res Commun. 1997:240(3):832-8.

49. Simon $\mathrm{D}$, et al. Clinical impact of retinoids in redifferentiation therapy of advanced thyroid cancer: final results of a pilot study. Eur J Nucl Med Mol Imaging. 2002;29(6):775-82.

50. Fernandez CA, et al. Effectiveness of retinoic acid treatment for redifferentiation of thyroid cancer in relation to recovery of radioiodine uptake. J Endocrinol Investig. 2009;32(3):228-33.

51. Zhang $Y$, et al. A clinical study of all-trans-retinoid-induced differentiation therapy of advanced thyroid cancer. Nucl Med Commun. 2007;28(4):251-5

52. Handkiewicz-Junak D, et al. 13-cis-retinoic acid re-differentiation therapy and recombinant human thyrotropin-aided radioiodine treatment of nonfunctional metastatic thyroid cancer: a single-center, 53-patient phase 2 study. Thyroid Res. 2009;2(1):8.

53. Presta I, et al. Recovery of NIS expression in thyroid cancer cells by overexpression of Pax8 gene. BMC Cancer. 2005;5:80

54. Kebebew $\mathrm{E}$, et al. A phase II trial of rosiglitazone in patients with thyroglobulin-positive and radioiodine-negative differentiated thyroid cancer. Surgery. 140(6):960-7.

55. Durante $C$, et al. BRAF mutations in papillary thyroid carcinomas inhibit genes involved in iodine metabolism. J Clin Endocrinol Metab. 2007;92(7): 2840-3.

56. Ho AL, et al. Selumetinib-enhanced radioiodine uptake in advanced thyroid cancer. N Engl J Med. 2013;368(7):623-32.

57. Riesco-Eizaguirre $\mathrm{G}$, et al. The BRAF $<$ sup $>\mathrm{V} 600 \mathrm{E}</$ sup $>$ oncogene induces transforming growth factor $\beta$ secretion leading to sodium iodide symporter repression and increased malignancy in thyroid cancer. Cancer Res. 2009; 69(21):8317-25.

58. Rothenberg SM, et al. Redifferentiation of iodine-refractory $<$ em $>$ BRAF $<$ / em> V600E-mutant metastatic papillary thyroid cancer with Dabrafenib. Clin Cancer Res. 2015;21(5):1028-35.

59. Kaufmann SHE. Immunology's foundation: the 100-year anniversary of the Nobel prize to Paul Ehrlich and Elie Metchnikoff. Nat Immunol. 2008;9(7):705-12.

60. Dunn GP, et al. Cancer immunoediting: from immunosurveillance to tumor escape. Nat Immunol. 2002;3(11):991-8.

61. Khalil DN, et al. The future of cancer treatment: immunomodulation, CARs and combination immunotherapy. Nat Rev Clin Oncol. 2016;13(5):273-90.

62. Farkona S, Diamandis EP, Blasutig IM. Cancer immunotherapy: the beginning of the end of cancer? BMC Med. 2016;14(1):73.

63. Kim S, et al. The expression of tumor-associated macrophages in papillary thyroid carcinoma. Endocrinol Metab (Seoul). 2013:28(3):192-8.

64. Ryder M, et al. Genetic and pharmacological targeting of CSF-1/CSF-1R inhibits tumor-associated macrophages and impairs BRAF-induced thyroid cancer progression. PLoS One. 2013;8(1):e54302

65. Pyonteck SM, et al. CSF-1R inhibition alters macrophage polarization and blocks glioma progression. Nat Med. 2013;19(10):1264-72.

66. Withers S, et al. Targeting Tumor-Associated Monocytes/Macrophages (TAMs) through the CSF-1/CSF-1R Pathway Restores Sensitivity of Advanced Thyroid Cancers to Cytotoxic Chemotherapy, in Metastasis and Tumor Progression: Cells Doing What They Shouldn't. p. OR45-6.

67. Wang X. Cancer moonshot 2020: a new march of clinical and translational medicine. Clinical and Translational Medicine. 2016;5:11.

68. Martins MB, et al. CD8+ TIL recruitment may revert the association of MAGE A3 with aggressive features in thyroid tumors. J Immunol Res. 2014;2014: 921864.

69. Milkovic M, Sarcevic B, Glavan E. Expression of MAGE tumor-associated antigen in thyroid carcinomas. Endocr Pathol. 2006;17(1):45-52.

70. Bieche I, et al. MUC1 mucin gene, transcripts, and protein in adenomas and papillary carcinomas of the thyroid. Thyroid. 1997;7(5):725-31.

71. Landa I, et al. Genomic and transcriptomic hallmarks of poorly differentiated and anaplastic thyroid cancers. J Clin Invest. 2016;126(3):1052-66.

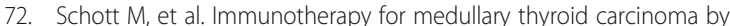
dendritic cell vaccination. J Clin Endocrinol Metab. 2001;86(10):4965-9.

73. Topalian SL, et al. Mechanism-driven biomarkers to guide immune checkpoint blockade in cancer therapy. Nat Rev Cancer. 2016;16(5):275-87

74. French JD, et al. Programmed death-1+ T cells and regulatory T cells are enriched in tumor-involved lymph nodes and associated with aggressive features in papillary thyroid cancer. J Clin Endocrinol Metab. 2012;97(6): E934-43. 
75. Mehnert AM, Varga A, Brose M, Aggarwal RR, Lin C-C, Prawira A, et al. Pembrolizumab for advanced papillary or follicular thyroid cancer: preliminary results from the phase 1b KEYNOTE-028 study. J Clin Oncol. 2016:34((suppl; abstr 6091)

76. Jaiswal $\mathrm{S}$, et al. CD47 is upregulated on circulating hematopoietic stem cells and leukemia cells to avoid phagocytosis. Cell. 2009;138(2):271-85.

77. Willingham SB, et al. The CD47-signal regulatory protein alpha (SIRPa) interaction is a therapeutic target for human solid tumors. Proc Natl Acad Sci U S A. 2012;109(17):6662-7.

78. Zhao XW, et al. CD47-signal regulatory protein-alpha (SIRPalpha) interactions form a barrier for antibody-mediated tumor cell destruction. Proc Natl Acad Sci U S A. 2011;108(45):18342-7.

79. Rath GM, et al. The C-terminal CD47//AP-binding domain of thrombospondin-1 prevents camptothecin- and doxorubicin-induced apoptosis in human thyroid carcinoma cells. Biochim Biophys Acta. 2006; 1763(10):1125-34.

80. Terme M, et al. VEGFA-VEGFR pathway blockade inhibits tumor-induced regulatory T-cell proliferation in colorectal cancer. Cancer Res. 2013;73(2): 539-49.

81. Angell TE, et al. BRAF V600E in papillary thyroid carcinoma is associated with increased programmed death ligand 1 expression and suppressive immune cell infiltration. Thyroid. 2014;24(9):1385-93.

82. Voron T, et al. VEGF-A modulates expression of inhibitory checkpoints on CD8+ T cells in tumors. J Exp Med. 2015;212(2):139-48.

83. Cabrera $R$, et al. Immune modulation of effector CD4+ and regulatory $T$ cell function by sorafenib in patients with hepatocellular carcinoma. Cancer Immunol Immunother. 2013;62(4):737-46.

84. Chen ML, et al. Sorafenib relieves cell-intrinsic and cell-extrinsic inhibitions of effector T cells in tumor microenvironment to augment antitumor immunity. Int J Cancer. 2014;134(2):319-31.

85. Woyach JA, et al. Lack of therapeutic effect of the histone deacetylase inhibitor vorinostat in patients with metastatic radioiodine-refractory thyroid carcinoma. J Clin Endocrinol Metab. 2009;94(1):164-70.

86. Brest $P$, et al. MiR-129-5p is required for histone deacetylase inhibitor-induced cell death in thyroid cancer cells. Endocr Relat Cancer. 2011;18(6):711-9.

87. $\mathrm{Xu} Y$, et al. Induction of apoptosis and autophagy in metastatic thyroid cancer cells by valproic acid (VPA). Int J Clin Exp Pathol. 2015;8(7):8291-7.

88. Damaskos $C$, et al. Histone deacetylase inhibitors: a novel therapeutic weapon against medullary thyroid cancer? Anticancer Res. 2016;36(10): 5019-24.

89. Nilubol N, et al. A phase II trial of valproic acid in patients with advanced, radioiodine-resistant thyroid cancers of follicular cell origin. Clin Endocrinol. 2017:86(1):128-33.

90. Catalano MG, et al. Valproic acid, a histone deacetylase inhibitor, in combination with paclitaxel for anaplastic thyroid cancer: results of a multicenter randomized controlled phase II/III trial. Int J Endocrinol. 2016;2016:8.

91. Kotian S, et al. Dual inhibition of HDAC and tyrosine kinase signaling pathways with CUDC-907 inhibits thyroid cancer growth and metastases. Clin Cancer Res. 2017;23(17):5044-54.

92. Li X, Wang Z. The role of noncoding RNA in thyroid cancer. Gland Surg. 2012;1(3):146-50.

93. Cho NL, et al. Global tyrosine kinome profiling of human thyroid tumors identifies Src as a promising target for invasive cancers. Biochem Biophys Res Commun. 2012;421(3):508-13.

94. Parker R, Clifton-Bligh R, Molloy MP. Phosphoproteomics of MAPK inhibition in BRAF-mutated cells and a role for the lethal synergism of dual BRAF and CK2 inhibition. Mol Cancer Ther. 2014;13(7):1894-906.

95. Martinez-Aguilar J, Clifton-Bligh R, Molloy MP. Proteomics of thyroid tumours provides new insights into their molecular composition and changes associated with malignancy. Sci Rep. 2016;6:23660.

96. Ciampi R, Nikiforov YE. Alterations of the BRAF gene in thyroid tumors Endocr Pathol. 2005;16(3):163-72.

97. Cohen $Y$, et al. BRAF mutation in papillary thyroid carcinoma. J Natl Cancer Inst. 2003:95(8):625-7.

98. Fagin JA. Genetics of papillary thyroid cancer initiation: implications for therapy. Trans Am Clin Climatol Assoc. 2005;116:259-69. discussion 269-71

99. Kimura ET, et al. High prevalence of BRAF mutations in thyroid cancer: genetic evidence for constitutive activation of the RET/PTC-RAS-BRAF signaling pathway in papillary thyroid carcinoma. Cancer Res. 2003;63(7):1454-7.

100. Kondo T, Ezzat S, Asa SL. Pathogenetic mechanisms in thyroid follicular-cell neoplasia. Nat Rev Cancer. 2006;6(4):292-306.
101. Namba H, et al. Clinical implication of hot spot BRAF mutation, V599E, in papillary thyroid cancers. J Clin Endocrinol Metab. 2003;88(9):4393-7.

102. Nikiforova MN, et al. BRAF mutations in thyroid tumors are restricted to papillary carcinomas and anaplastic or poorly differentiated carcinomas arising from papillary carcinomas. J Clin Endocrinol Metab. 2003;88(11):5399-404.

103. Wan PT, et al. Mechanism of activation of the RAF-ERK signaling pathway by oncogenic mutations of B-RAF. Cell. 2004;116(6):855-67.

104. Xing $M$, et al. BRAF mutation predicts a poorer clinical prognosis for papillary thyroid cancer. J Clin Endocrinol Metab. 2005;90(12):6373-9.

105. Basolo F, et al. N-ras mutation in poorly differentiated thyroid carcinomas: correlation with bone metastases and inverse correlation to thyroglobulin expression. Thyroid. 2000;10(1):19-23.

106. Ezzat $\mathrm{S}$, et al. Prevalence of activating ras mutations in morphologically characterized thyroid nodules. Thyroid. 1996;6(5):409-16.

107. Fagin JA. Minireview: branded from the start-distinct oncogenic initiating events may determine tumor fate in the thyroid. Mol Endocrinol. 2002;16(5):903-11.

108. Hara $\mathrm{H}$, et al. $\mathrm{N}$-ras mutation: an independent prognostic factor for aggressiveness of papillary thyroid carcinoma. Surgery. 1994;116(6):1010-6.

109. Namba H, Rubin SA, Fagin JA. Point mutations of ras oncogenes are an early event in thyroid tumorigenesis. Mol Endocrinol. 1990;4(10):1474-9.

110. Suarez HG, et al. Presence of mutations in all three ras genes in human thyroid tumors. Oncogene. 1990;5(4):565-70.

111. Zhu Z, et al. Molecular profile and clinical-pathologic features of the follicular variant of papillary thyroid carcinoma. An unusually high prevalence of ras mutations. Am J Clin Pathol. 2003:120(1):71-7.

112. Fusco $A$, et al. A new oncogene in human thyroid papillary carcinomas and their lymph-nodal metastases. Nature. 1987;328(6126):170-2.

113. Grieco $M$, et al. PTC is a novel rearranged form of the ret proto-oncogene and is frequently detected in vivo in human thyroid papillary carcinomas. Cell. 1990;60(4):557-63.

114. Jhiang SM, et al. Targeted expression of the ret/PTC1 oncogene induces papillary thyroid carcinomas. Endocrinology. 1996;137(1):375-8.

115. Powell DJ Jr, et al. The RET/PTC3 oncogene: metastatic solid-type papillary carcinomas in murine thyroids. Cancer Res. 1998;58(23):5523-8.

116. Santoro $M$, et al. Development of thyroid papillary carcinomas secondary to tissue-specific expression of the RET/PTC1 oncogene in transgenic mice. Oncogene. 1996;12(8):1821-6.

117. Santoro $M$, et al. Molecular characterization of RET/PTC3; a novel rearranged version of the RETproto-oncogene in a human thyroid papillary carcinoma. Oncogene. 1994;9(2):509-16.

118. Santoro M, et al. The TRK and RET tyrosine kinase oncogenes cooperate with ras in the neoplastic transformation of a rat thyroid epithelial cell line. Cell Growth Differ. 1993;4(2):77-84.

119. Tallini G, Asa SL. RET oncogene activation in papillary thyroid carcinoma. Adv Anat Pathol. 2001;8(6):345-54.

120. French CA, et al. Genetic and biological subgroups of low-stage follicular thyroid cancer. Am J Pathol. 2003:162(4):1053-60.

121. Giordano TJ, et al. Delineation, functional validation, and bioinformatic evaluation of gene expression in thyroid follicular carcinomas with the PAX8-PPARG translocation. Clin Cancer Res. 2006;12(7 Pt 1):1983-93.

122. Gregory Powell J, et al. The PAX8/PPARgamma fusion oncoprotein transforms immortalized human thyrocytes through a mechanism probably involving wild-type PPARgamma inhibition. Oncogene. 2004:23(20):3634-41.

123. Kroll TG, et al. PAX8-PPARgamma1 fusion oncogene in human thyroid carcinoma [corrected]. Science. 2000;289(5483):1357-60.

124. Nikiforova MN, et al. RAS point mutations and PAX8-PPAR gamma rearrangement in thyroid tumors: evidence for distinct molecular pathways in thyroid follicular carcinoma. J Clin Endocrinol Metab. 2003;88(5):2318-26.

125. Reddi HV, et al. The paired box-8/peroxisome proliferator-activated receptor-gamma oncogene in thyroid tumorigenesis. Endocrinology. 2007; 148(3):932-5.

126. Landa I, et al. Frequent somatic TERT promoter mutations in thyroid cancer: higher prevalence in advanced forms of the disease. J Clin Endocrinol Metab. 2013:98(9):E1562-6.

127. Malaguarnera $\mathrm{R}$, et al. Switch in signaling control of mTORC1 activity after oncoprotein expression in thyroid cancer cell lines. J Clin Endocrinol Metab. 2014;99(10):E1976-87.

128. Liu R, Xing M. TERT promoter mutations in thyroid cancer. Endocr Relat Cancer. 2016;23(3):R143-55.

129. Taccaliti $A$, et al. Genetic alterations in medullary thyroid cancer: diagnostic and prognostic markers. Curr Genomics. 2011;12(8):618-25. 
130. Cohen EE, et al. Axitinib is an active treatment for all histologic subtypes of advanced thyroid cancer: results from a phase II study. J Clin Oncol. 2008; 26(29):4708-13.

131. Sherman SI, et al. Motesanib diphosphate in progressive differentiated thyroid cancer. N Engl J Med. 2008;359(1):31-42.

132. Carr LL, et al. Phase II study of daily sunitinib in FDG-PET-positive, iodine-refractory differentiated thyroid cancer and metastatic medullary carcinoma of the thyroid with functional imaging correlation. Clin Cancer Res. 2010;16(21):5260-8.

133. Bible KC, et al. Efficacy of pazopanib in progressive, radioiodine-refractory, metastatic differentiated thyroid cancers: results of a phase 2 consortium study. Lancet Oncol. 2010;11(10):962-72.

134. Lim SM, et al. An open label, multicenter, phase II study of dovitinib in advanced thyroid cancer. Eur J Cancer. 2015;51(12):1588-95.

135. de Groot JWB, et al. A phase II trial of Imatinib therapy for metastatic medullary thyroid carcinoma. J Clin Endocrinol Metab. 2007;92(9):3466-9.

136. Falchook GS, et al. BRAF inhibitor dabrafenib in patients with metastatic BRAF-mutant thyroid cancer. Thyroid. 2015;25(1):71-7.

137. Brose MS, et al. Vemurafenib in patients with BRAF(V600E)-positive metastatic or unresectable papillary thyroid cancer refractory to radioactive iodine: a non-randomised, multicentre, open-label, phase 2 trial. Lancet Oncol. 2016;17(9):1272-82.

138. Cunha $L L$, et al. Infiltration of a mixture of immune cells may be related to good prognosis in patients with differentiated thyroid carcinoma. Clin Endocrinol. 2012;77(6):918-25.

139. French JD, et al. Tumor-associated lymphocytes and increased FoxP3+ regulatory $\mathrm{T}$ cell frequency correlate with more aggressive papillary thyroid cancer. J Clin Endocrinol Metab. 2010;95(5):2325-33.

140. Kumar A, et al. Significance of antithyroglobulin autoantibodies in differentiated thyroid carcinoma. Thyroid. 1994;4(2):199-202.

141. Pacini F, et al. Thyroid autoantibodies in thyroid cancer: incidence and relationship with tumour outcome. Acta Endocrinol. 1988;119(3):373-80.

142. Spencer CA, et al. Serum thyroglobulin autoantibodies: prevalence, influence on serum thyroglobulin measurement, and prognostic significance in patients with differentiated thyroid carcinoma. J Clin Endocrinol Metab. 1998:83(4):1121-7.

143. Melillo RM, et al. Mast cells have a protumorigenic role in human thyroid cancer. Oncogene. 2010;29(47):6203-15.

144. Proietti A, et al. Higher intratumoral expression of CD1a, tryptase, and CD68 in a follicular variant of papillary thyroid carcinoma compared to adenomas: correlation with clinical and pathological parameters. Thyroid. 2011;21(11):1209-15.

145. Visciano C, et al. Mast cells induce epithelial-to-mesenchymal transition and stem cell features in human thyroid cancer cells through an IL-8Akt-slug pathway. Oncogene. 2015;34(40):5175-86.

146. Speiser DE, Ho P-C, Verdeil G. Regulatory circuits of T cell function in cancer. Nat Rev Immunol. 2016;16(10):599-611.

147. Bastman JJ, et al. Tumor-infiltrating T cells and the PD-1 checkpoint pathway in advanced differentiated and anaplastic thyroid cancer. J Clin Endocrinol Metab. 2016;101(7):2863-73.

148. Wherry EJ. T cell exhaustion. Nat Immunol. 2011;12(6):492-9.

149. Severson JJ, et al. PD-1+Tim-3+ CD8+ T lymphocytes display varied degrees of functional exhaustion in patients with regionally metastatic differentiated thyroid cancer. Cancer Immunol Res. 2015;3(6):620-30.

150. Angell TE, et al. MHC class I loss is a frequent mechanism of immune escape in papillary thyroid cancer that is reversed by interferon and selumetinib treatment in vitro. Clin Cancer Res. 2014;20(23):6034-44.

151. Boros P, Balazs G, Szegedi G. Natural killer activity in thyroid cancer patients. Haematologia (Budap). 1987;20(3):189-93.

152. Gogali F, et al. Phenotypical analysis of lymphocytes with suppressive and regulatory properties (Tregs) and NK cells in the papillary carcinoma of thyroid. J Clin Endocrinol Metab. 2012;97(5):1474-82.

153. Modi J, et al. Papillary thyroid carcinomas from young adults and children contain a mixture of lymphocytes. J Clin Endocrinol Metab. 2003;88(9):4418-25.

154. Parhar RS, et al. IL-12 immunotherapy of Braf(V600E)-induced papillary thyroid cancer in a mouse model. Lab Investig. 2016;96(1):89-97.

155. Wennerberg $E$, et al. Human anaplastic thyroid carcinoma cells are sensitive to NK cell-mediated lysis via ULBP2/5/6 and chemoattract NK cells. Clin Cancer Res. 2014;20(22):5733-44.
156. Xu X, et al. Clinicopathological significance of major histocompatibility complex class I-related chain a and B expression in thyroid cancer. J Clin Endocrinol Metab. 2006;91(7):2704-12.

157. Qing W, et al. Density of tumor-associated macrophages correlates with lymph node metastasis in papillary thyroid carcinoma. Thyroid. 2012;22(9): 905-10.

158. Ryder M, et al. Increased density of tumor-associated macrophages is associated with decreased survival in advanced thyroid cancer. Endocr Relat Cancer. 2008;15(4):1069-74.

159. Caillou B, et al. Tumor-associated macrophages (TAMs) form an interconnected cellular supportive network in anaplastic thyroid carcinoma. PLoS One. 2011;6(7):e22567.

160. Batistatou A, Zolota V, Scopa CD. S-100 protein+ dendritic cells and CD34+ dendritic interstitial cells in thyroid lesions. Endocr Pathol. 2002;13(2):111-5.

161. Ugolini $C$, et al. Lymphocyte and immature dendritic cell infiltrates in differentiated, poorly differentiated, and undifferentiated thyroid carcinoma. Thyroid. 2007;17(5):389-93.

162. Scarpino S, et al. Papillary carcinoma of the thyroid: hepatocyte growth factor (HGF) stimulates tumor cells to release chemokines active in recruiting dendritic cells. Am J Pathol. 2000;156(3):831-7.

163. Baba T, et al. Novel process of intrathymic tumor-immune tolerance through CCR2-mediated recruitment of Sirpalpha+ dendritic cells: a murine model. PLoS One. 2012;7(7):e41154.

\section{Submit your next manuscript to BioMed Central and we will help you at every step:}

- We accept pre-submission inquiries

- Our selector tool helps you to find the most relevant journal

- We provide round the clock customer support

- Convenient online submission

- Thorough peer review

- Inclusion in PubMed and all major indexing services

- Maximum visibility for your research

Submit your manuscript at www.biomedcentral.com/submit

) Biomed Central 